\title{
ESTIMATION OF TRIP GENERATION RATES FOR RESIDENTIAL LAND USE IN UYO, NIGERIA
}

\author{
I. N. Usanga ${ }^{1}$, R. K. Etim ${ }^{2}$ * and V. Umoren ${ }^{3}$ \\ 1, 2, Dept of Civil Engineering, AKWa Ibom State Univ., IKot AKpaden, AKWa Ibom State, Nigeria \\ 3, Department of Urban and Regional Planning, UniV. OF UYO, UYO, AKWA IBOm STATE, NIGERIA. \\ Email addresses: 1 usangaidy@gmail.com, ${ }^{2}$ rolandetim@aksu.edu.ng, ${ }^{3}$ victorumoren@uniuyo.edu.ng
}

\begin{abstract}
Change in trip rates affects a transportation system and could lead to the redesign of the transport infrastructure in order to satisfy the new demand. This study estimates trip generation rates for residential land use in Uyo using cross classification method. Five (5) residential estates were considered and household survey carried out to collect trip data from 500 households on purpose and mode of travel through household interview and their response recorded in questionnaire. Four independent variables (household size, household income, car ownership, number of employed persons) were used for the study based on the prevailing conditions of the residential land use. Cross-classification trip rates were developed from the most significant variables; household size, household income and car ownership. The analysis indicated that work trip produced the highest reported trip rates of $29.6 \%$ followed by religious trip of $24.7 \%$. Similarly, private car trips contributed $\mathbf{4 2 . 8 \%}$ of trips made by mode of travel as the highest trip. It was found that household size is the strongest socio-economic variable that influence trip generation in residential land use in Uyo. The cross-classification trip rates developed in this study could provide basis for the estimation of trip generation in residential land use in Uyo.
\end{abstract}

Keywords: Trip generation; analysis of variance, ANOVA; cross classification

\section{INTRODUCTION}

Travel demand forecasting plays an important role as a major contributor to the planning tools used both in new transportation facilities or evaluating existing system. Transportation of people and goods is a medium of activity, and is the joint consequence of the land-use potential and the traffic carrying capabilities of various modes of transportation [1]. The most important component of travel behavior is the decision to travel for a given purpose which is known as trip generation. The study of [2] demonstrated higher accuracy of the Radial Basis Function Neural Network (RBFNN) in producing trip generation forecasts in high density residential zone of Akure, Nigeria. Trip generation is one of the two kinds of trip analysis. It refers to the trips generated by residential zones where these trips may be trip origins or trip destination. A trip generation model predicts the number of home-based trips to and from where trip maker lives [3]. Travel demands analysis has been a major component of transportation planning in the developed world for many decades [4]. The increasing demands for motorized transportation due to increasing number of private vehicles and other socio-economic factors in almost all developing countries has called for concern. In Nigeria, virtually every state capital city today faces the problem of traffic congestion [5]. Estimation of trip generation rates within an area could serve as precursor to provision of facilities to tackle anticipated transportation problem in area. This is why the development of adequate transportation plan or evaluation of existing facilities for an urban area is dependent on the envisaged trip rates in the urban area [6]. 
Uyo is rapidly emerging as a metropolitan city, the increase in population due to the massive infrastructure development has resulted in higher number of residential land use. Oron road accommodates the highest number of residential land use in Uyo. These includes; Ewet Housing Estate, Osongama Estate, Akpasak Estate, Shelter Afrique Estate and Joyce Global Estate. It is important to estimate trips production rate in these residential areas and also understand the socioeconomic factors that affect trip production based on the prevailing conditions of these areas. The heavy traffic situation observed in Oron road especially during the peak period has called for concern in understanding the frequency of trips generated in the residential areas in order to achieve sustainability in the urban transportation system. Trip generation models conducted by [6] in Uyo capital city, focused on multiple regression analysis technique. This technique was on the basis of zonal variables which were aggregated and this resulted in an adverse situation where the equations were dependent to a certain degree on the particular zoning system that was employed by Al-Masaeid and Fayyad [7]. They estimated trip generation rates for residential areas in Jordan using regression analysis and crossclassification methods. They concluded that crossclassification approach provided closer estimates when compared with regression analysis.

Several studies have been conducted in Nigeria and elsewhere concerning trip generation estimation and the factors that govern trip generation rates. Residential trip generation rates are fundamental components of transportation planning [8]. Miller et al., [9] conducted the household surveys in four residential neighborhoods in order to determine trip generation rates from travels made by individual households in the neighborhoods. The obtained rates were compared with the national trip generation rates provided in the manual by the Institute of Transportation Engineers (ITE). Generally, rates obtained in the study were different from the manual rates. Single family detached house indicated slight difference between site-specific household surveys and ITE's trip generation rates. Al-Masaeid and Fayyad [7] conducted a study to develop trip generation for residential areas. Household survey was carried out to collect data on trips and their purposes on typical workdays and holidays. Analysis carried out in the study indicated that the number of generated trips is influenced by family size, car ownership and income level. The study further indicated that the number of homebased work trips constituted about one-third of the total home-based trips. Also, it was found that the numbers of trips on holidays represent nearly onethird of the number of trips generated on workdays. Justin, et. al. [10] modeled a household trip generation in Ado-Ekiti using regression model. The study showed that people with higher income and less automobile availability make more trips than people with low income and less automobile availability. The study also indicated that home base trips takes the largest percentage (52\%) of people in Ado-Ekiti while non-home base work contributes $31 \%$ and $17 \%$ respectively. In a study by [6] on trip generation models for a developing city in Nigeria, regression models were formulated for estimating future work trips, market trips, health trips, funeral trips and wedding trips. Justin et al. [11] reported a comparative analysis trip model using home base work trip in city of Seoul, South Korea. Also, [12] conducted a study on trip generation analysis in a developing country context using category analysis technique. The study revealed that large household size reflecting the extended family system in developing countries significantly affect trip making. The study further indicated that car ownership and number of employed persons in the household is the major factor that influence household trip production.

This study investigates trip generation in residential areas with the aim of assessing the precise and comprehensive information on travel demand characteristics of household. This study therefore set out to determine the influence of trip generation on purpose and mode of travel of household in an emerging city such as Uyo, Akwa Ibom state, Nigeria. The outcome of this study is expected to play a major role in transportation and facility planning that would address the current and future transportation, land use, economic development, traffic demand, public safety and social needs.

\section{STUDY AREA}

This study was carried out in Uyo (Figure 1). Uyo is the capital of Akwa Ibom state created in 1987 and located at the south-south region of Nigeria, thus having tropical climate condition.. 


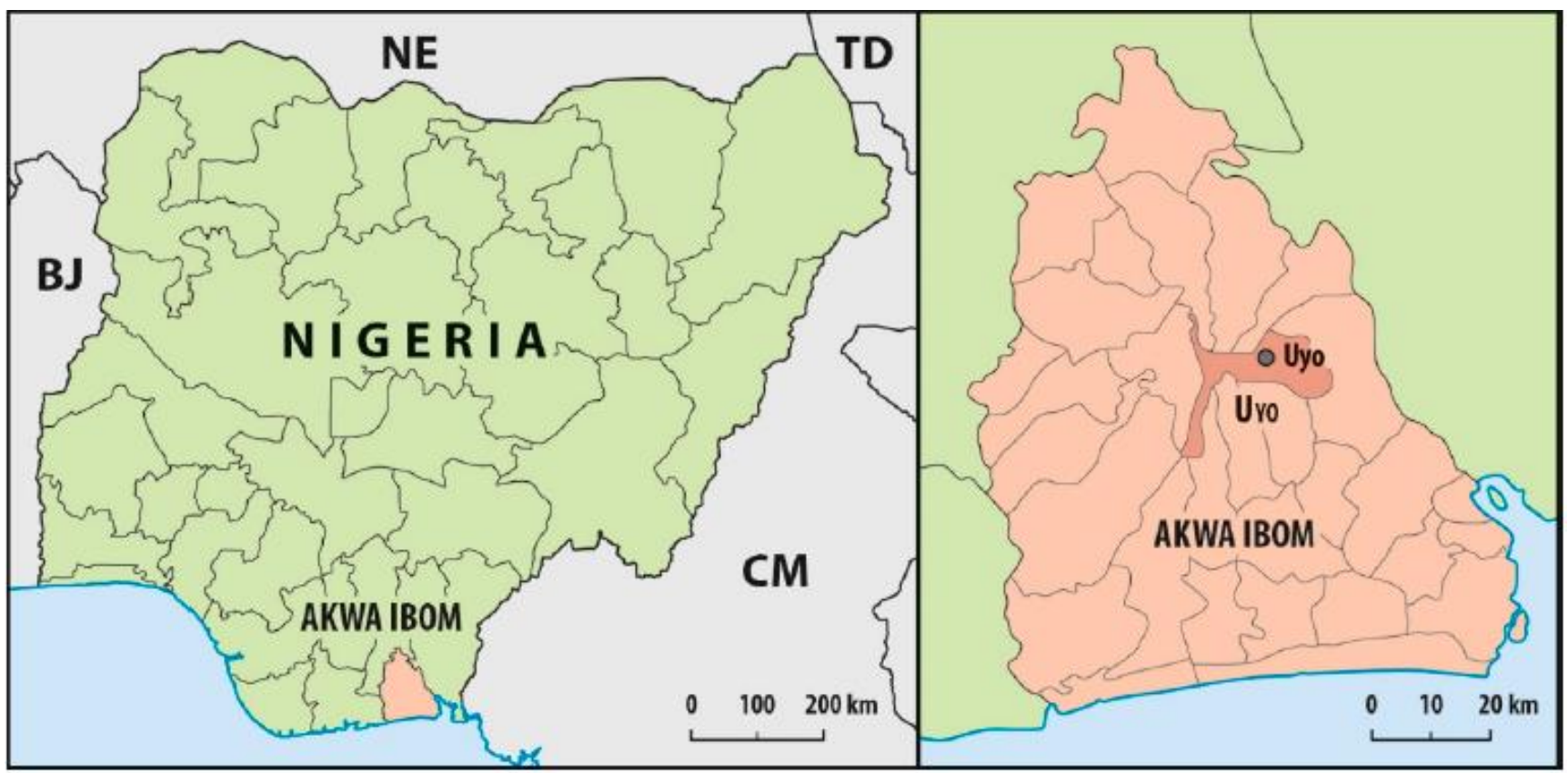

Figure 1. Map of Nigeria showing Akwa Ibom State, and map of Akwa Ibom State showing Uyo capital city (Source: Ministry of Land Surveying, Uyo).

The city lies between longitudes $37^{\circ} 50^{\prime} \mathrm{E}$ and $37^{\circ}$ $51^{\prime} \mathrm{E}$, and between latitudes $55^{\circ} 40^{\prime} \mathrm{N}$ and $54^{\circ} 59^{\prime}$ $\mathrm{N}$. Uyo has a total area of $188.035 \mathrm{~km}^{2}$ and an estimated population of $3.920,208$ [13-14]. In the past nine years, there has been massive increase in infrastructural growth in Uyo, leading to the city becoming a fast growing one in Nigeria. The increase in infrastructure has resulted in increase in number of residential districts. Uyo is home to many notable housing districts such as: Ewet housing estate, Abak road housing estate, Osongama housing estate, Shelter Afrique housing estate, Akpasak housing estate, Joyce global housing estate, Akwa Ima Housing Estate. Oron Road in Uyo accommodate the highest number of these residential land use and hence heavy traffic situation is usually observed especially during the peak period.

\section{METHODOLOGY AND DATA COLLECTION}

\subsection{Interview and questionnaire administration}

Interview was conducted and questionnaire was also administered to house hold resident in five selected of the seven major residential estates in Uyo. These estates included; Ewet, Osongama, Shelter Afrique, Akpasak and Joyce global housing estate. These five where selected based on their concentration in one segment of the city and each forming a land use cluster that could possibly account for the saturation flow of persons and traffic within Oron road of city.
These residential estates were also selected based on similar socio-economic characteristics considering property rating.

The selected residential estates consisted of three (3) high-income residential estate (Ewet Housing Estate, Shelter Afrique Estate and Osongama Estate), one medium income estate (Akpasak Estate) and one low income residential estate (Joyce global Estate). Households were randomly selected and interviewed at their homes on Sundays, Mondays, Wednesdays, Fridays and Saturdays between the hours of 7:30am - 10:30am from August, 2019 to February, 2020. This period was selected in order to have respondents at home due to higher number of holidays that fall within this period. The sample size of number of households in the five (5) selected residential estate were obtained based on data from Port Harcourt Electricity Distribution Company (PHEDC) (Table 1). The selected residential estates had a total of 2,646 households. Systematic random sampling technique was adopted to select the sample size from the population Kadiyali [15] as shown in Table 2. A recommended sample size of 1:5 was applied since the population of the study area was below 50,000. 500 households which represent 1 in every 5 households were interviewed and their responses recorded in questionnaire sheet. 


\subsection{Grouping of variables}

Four independent variables; household size, household income, number of cars owned and number of employed persons per household were considered in this study. Household size was grouped into three categories: 1 to 5,6 to 10 and more than 11. It is defined as a group of persons who make common provision of food, shelter and other essentials for living.

Table 1: Sample size and average household size

\begin{tabular}{llcl}
\hline $\begin{array}{l}\text { Residential } \\
\text { estate }\end{array}$ & $\begin{array}{l}\text { Number of } \\
\text { household }\end{array}$ & $\begin{array}{l}\text { Sample } \\
\text { size }\end{array}$ & $\begin{array}{l}\text { Average } \\
\text { household }\end{array}$ \\
\hline $\begin{array}{l}\text { Ewet Housing } \\
\text { estate }\end{array}$ & 900 & 180 & 4.10 \\
$\begin{array}{l}\text { Shelter Afrique } \\
\text { Housing estate }\end{array}$ & 744 & 149 & 4.61 \\
$\begin{array}{l}\text { Osongama } \\
\text { Housing }\end{array}$ & 460 & 92 & 4.23 \\
$\begin{array}{l}\text { Akpasak } \\
\text { Housing Estate }\end{array}$ & 300 & 60 & 5.11 \\
$\begin{array}{l}\text { Joyce global } \\
\text { Estate }\end{array}$ & 60 & 13 & 5.82 \\
Total & 2,464 & 494 &
\end{tabular}

Source: Authors field work (2019)

Table 2: sample size for the home interview survey

\begin{tabular}{lcc}
\hline Population of & \multicolumn{2}{c}{ Sample size } \\
\cline { 2 - 3 } $\begin{array}{l}\text { Study area } \\
\text { Under } 50,000\end{array}$ & Minimum & recommended \\
\cline { 2 - 3 } $50,000-$ & 1 in 10 & 1 in 5 \\
150,000 & 1 in 20 & 1 in 8 \\
$150,000-$ & 1 in 35 & 1 in 10 \\
300,000 & 1 in 50 & 1 in 15 \\
$300,000-$ & 1 in 70 & 1 in 20 \\
500,000 & 1 in 100 & 1 in 25 \\
$500,000-$ & Source: Kadiyali [15] \\
$1,000,000$ & \\
Over 1 million &
\end{tabular}

Household income is a measure of the combined incomes of all people sharing a particular household or place of residence. It includes every form of income like; salaries and wages, retirement income and investment gains. The preferred form of household income in this study was the income of the head of household. Household income was categorized into five levels of income: below

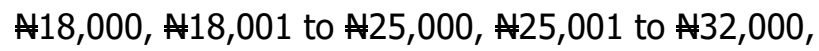
$\$ 32,001$ to $\$ 40,000$ and $\$ 41,001$ and above. The range of these income was considered because it reflected the socio-economic grading of the high and low residential estate as at the period this survey was conducted. Car ownership represents ease in mobility. The study classified car ownership into three categories; 0,1 to 2 , and more than 2 . The grouping can be said to also show the difference in our socio-economic value. The trip making behavior is propelled by the number of the employed persons in the household. This study refers to the number of full-time and or part-time workforces. The number of employed persons was grouped into three categories; 1 to 2,3 to 4 and 5 and above.

\subsection{Trip Rate Analysis}

The trip generation rate referred in [12] was used in this study. This study considered each household variable $(x)$ and category $(y)$ in estimating the trip production rate by purpose and mode of travel for each socio-economic factors (independent variable). Based on these classifications, equation (1) is used in the computation of trip rates generated.

$$
\mathrm{t}_{\mathrm{xy}}^{\mathrm{p} / \mathrm{m}}=\frac{\mathrm{N}_{\mathrm{xy}}^{\mathrm{p} / \mathrm{m}}}{\mathrm{H}_{\mathrm{xy}}}
$$

where $t_{x y}^{p / m}$ trip rate for purpose or mode of travel, $\mathrm{N}_{\mathrm{xy}}^{\mathrm{p} / \mathrm{m}}=$ Number of trips for purpose or mode of travel per day and $\mathrm{H}_{\mathrm{xy}}=$ Number of households in that category. The purpose of trip makers considered were grouped into five categories: work, school, shopping, religion and others representing trip made to transfer from one mode to another, to wedding, business, health and recreation. The trip- purpose were restricted to home-based trips. The modes for making the trips were grouped into, private car, minibus /tricycle, and walking.

\subsection{Analysis of variance}

Based on the trip rate by purpose and mode of travel, One-way analysis of variance (ANOVA) was carried out using statistical package for social sciences (SPSS). The ANOVA is used to establish the variables with the strongest relationship to trip making. Cross classification scheme (category analysis) was further used to analyze the trips made because it permits a more comprehensive analysis of trip making by showing the relationships among different classes of households. It could also be a better method when the data are insufficient 
because of large standard errors and uncertainty in model parameters associated with small sample sizes. It does not require a linear or monotonic relationship between the variables.

\section{RESULTS AND DISCUSSION}

\subsection{Trips rates by purpose}

How household size, household income, and the number of employed persons per household influence trip generation rate by purpose is shown in Table 3. It can be observed generally that the higher the number range of persons in the household the more the trip generated for all trip purpose. The trends in household trip can be seen in the order of persons going out for religious activities, work, shopping, school and other non-classified activities. Typically, household having 1 to 5 persons generated 0.94 and 0.84 religion and work trips, respectively. Also, the equivalent trip for 6 to 10 persons are 1.40 and 1.30 trips. In the same way, trip rates generated by purpose of school, shopping and other related activities increased with number of persons in each of the household. The observation of increase in trip rates which is more obvious in religious and work is due to the fact that the study area is undertaken in residential land uses of urban area where religious affiliation of the people is seen as very paramount jointly with high employment engagement. The influence of household income on the trip rate purpose can also be seen in the second part of Table 3. Household with higher income generated more trips than those with lower income. The difference in trips rates for religious trip was almost in significant because religious trips is a basic trip each household must embark upon irrespective of its financial circumstance. Trip rates for other trips were higher as household income increases. This is because household with higher income can afford to undertake recreational, wedding and business trips. The number of employed persons in the household had effect on work, school, shopping and other trip rates (see Table 3 ) as the number of persons employed increased with trip rates. In contrast, religious trips decreased with increased number of employed persons. Although the trip rate for religion are comparatively higher compared to school, shopping and others, increasing household number of employed persons is indirectly proportional to the trip made for religion purpose. This is because household embark on religious trip for primary purpose of sharing faith and fellowshipping together which does not depend on the number of employed persons.

\subsection{Trip rate by mode}

Trip rates by mode of travel is presented in Table 4. It shows the influence of household size, income and car ownership on the mode of travel. It is observed that the use of private cars increases with increase in household size which could this be related to economic status of members of the household. This is in contrast with the study conducted by [11] which was not affected by the household size. Household size in all categories had high trip rate with lower usage in mini buses/tricycles as well walking. This is because the study considers more of high income residential units which have more desire for private vehicle ownership. It could also be as a results of decline in the operation of public transport services which delays travel time, cause inconvenience and occasionally none cost effective. Also, from Table 4, it can be seen that household income increases with increase in private car usage. Low income household below $\$ 18,000$ and $\$ 25,000$ engage more in public transport (mini buses and tricycles) and walking trip. This category of income earners secures jobs close to their places of residence which is characterized by low transport fare. Increase in car ownership does not have significant influence in the use of mini buses/tricycles. As car ownership increases, private car trips also increases.

\subsection{Total trip rate generated}

Total trip rates generated by residential land use in this study were estimated and summarized under two categories, trip purpose and mode of travel. Figure 2 reveals that the most important trip purpose based on their percentage contribution on total trip rate generated is work trip which produced $29.6 \%$ of the total trip rate, followed by religious trip that made $24.7 \%$. Shopping trip, school trip and other trips which include trips to wedding, recreation and health represent $19.7 \%, 16.5 \%$ and $9.4 \%$, respectively. Clearly, the trip "other" indicated the least contribution to the total trip rates generated. Figure 3 also present private car as the highest trip rate generated by travel mode with $42.8 \%$, mini bus/tricycles $34.5 \%$ and walking trip $22.6 \%$ as the least trip rate generation in the study. The high percentage trip made by private car could be partly due to the socio economic standard of persons within the location considered in this study. 
Estimation of Trip Generation RATES fOR Residential LAND USE IN Uyo, NIGERIA， I. N. Usanga, R. K. Etim and V. Umoren

Table 3: Household trip rates produced by purpose of travel

\begin{tabular}{lllllll}
\hline Category of household & & Work & School & Shopping & Religion & Other \\
\hline \multirow{3}{*}{ House hold size } & $1-5$ & 0.84 & 0.63 & 0.64 & 0.94 & 0.29 \\
& $6-10$ & 1.30 & 0.69 & 0.87 & 1.40 & 0.32 \\
& $>11$ & 1.76 & 1.25 & 1.27 & 1.86 & 0.35 \\
\hline \multirow{4}{*}{ Household monthly } & $<18000$ & 0.78 & 0.64 & 0.36 & 1.18 & 0.30 \\
income (A) & $18001-25000$ & 0.82 & 0.80 & 0.66 & 1.16 & 0.67 \\
& $25001-32000$ & 1.64 & 0.94 & 1.22 & 1.14 & 0.91 \\
& $32001-40000$ & 2.04 & 1.09 & 1.28 & 1.12 & 1.21 \\
\multirow{2}{*}{ Number of employed } & $1-2$ & 2.15 & 0.99 & 1.29 & 1.10 & 1.50 \\
person in household & $3-4$ & 2.51 & 1.32 & 1.93 & 2.61 & 0.26 \\
& $>5$ & 3.34 & 1.52 & 2.08 & 2.51 & 0.29 \\
\hline
\end{tabular}

Table 4: Household trip rates produced by mode of travel

\begin{tabular}{lllll}
\hline Category of household & & Private car & Mini bus and tricycle & Walking \\
\hline \multirow{3}{*}{ House hold size } & $1-5$ & 1.54 & 0.64 & 0.71 \\
& $6-10$ & 1.60 & 0.72 & 1.00 \\
& $>10$ & 1.67 & 0.80 & 1.51 \\
\hline \multirow{4}{*}{ Household monthly } & $<18000$ & 0.42 & 1.71 & 0.82 \\
income (\#) & $18001-25000$ & 0.65 & 1.51 & 0.72 \\
& $25001-32000$ & 0.83 & 1.33 & 0.61 \\
& $32001-40000$ & 1.16 & 0.91 & 0.55 \\
Household car ownership & $1-2$ & 1.51 & 0.64 & 0.32 \\
& $>40000$ & 2.01 & 1.60 & 0.96 \\
& 0 & 2.20 & 1.60 & 0.80 \\
\hline
\end{tabular}

\subsection{Cross-Classification matrix}

In order to determine the variables that seem to have the strongest relationships to trip making by purpose and mode of travel, and also the best grouping of data to use in forming the crossclassification matrix, a one-way analysis of variance (ANOVA) was used.

The ANOVA by trip purpose and mode of travel are presented in the Table 5 and 6 . The result of the show that household size was significant for all trip purpose and mode of travel. Similarly, household income was more significant than household number of employed persons in trip purpose. Consequently, household income was consistent for all trip purposes except religious trips. Interestingly, household income also performs satisfactory for trip by mode except for walking trips.

Car ownership was most significant for all mode of travel. It is observed that household size is the strongest socio-economic variable that relate to trip making for residential land use of the study area since its significant across various trip purposes and mode of travel. Based on their level of significance, household size, household income and car ownership can be selected as the suitable grouping for crossclassification trip rates. Number of employed persons though significant for work, school and shopping was not significant for religious and other trips.

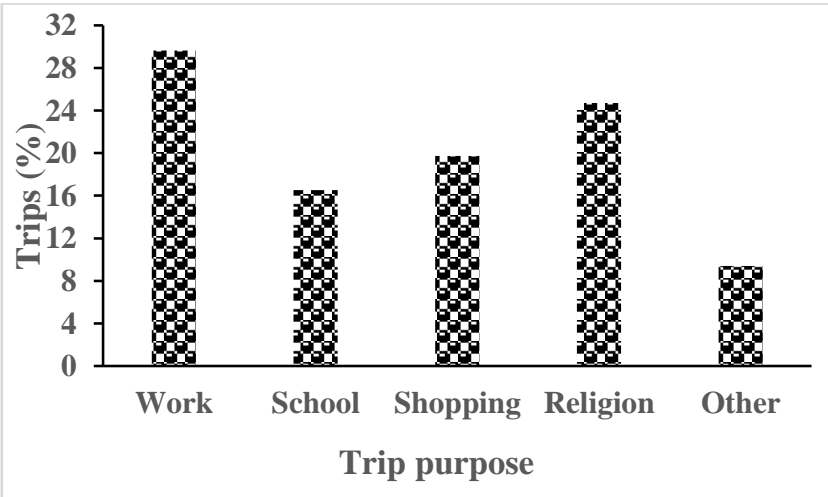

Figure 2: Total trip rates generated by purpose of travel. 


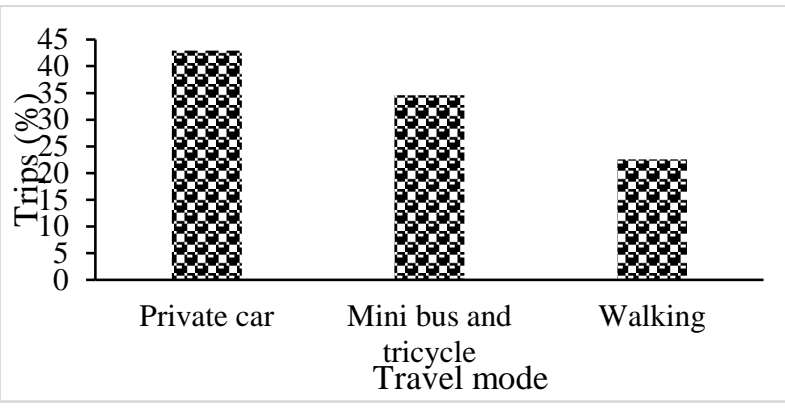

Figure 3: Total trip rates generated by mode of travel.

The insignificance of number of employed persons to religious and other trips is due to the fact that religious, wedding, recreation, health etc. do not depend on number of employed persons in the household. Most households in developing country depend solely on the head of the family and hence it is common to have one employed person in the family [12].

The cross classification rates developed in Table 7-9 present trip rates of the most significant socio- economic variables. The vacant cells in table 7 reflect that household size above five (5) had no bearing for an income below 118,000 and same is applicable to household size above ten (10) with income below A25,000. This shows that high cost of living in Uyo does not permit large household with meagre income. High trip rates are linked to households of 6-10 members with monthly income of above A1,000. Similarly, high trip is observed in household size of 6-10 members with more than 2 cars in Table 8. Table 9 revealed vacant cell for households that own one or two cars with monthly income below A18,000 and the same with households of two cars with monthly income below N25,000. This indicates that high household income larger than $\$ 25,000$ and household having more than two cars will generate more trips than household earning either less or high but with less than two cars. The highest number of trips generated is only observed in household that own two and above cars with monthly income above A 40,000 .

Table 5: ANOVA results by trip purpose

$a=$ significant at $95 \%$ or beyond; $b=$ not significant at $95 \%$ of beyond, SS = sum of squares, $F=F$ Score, df $=$ degree of freedom.

\begin{tabular}{|c|c|c|c|c|c|c|c|}
\hline \multirow[b]{2}{*}{ Variable } & \multirow[b]{2}{*}{ Category } & \multirow[b]{2}{*}{ Statistics } & \multicolumn{5}{|c|}{ Trip by purpose } \\
\hline & & & Work & School & Shopping & Religion & Others \\
\hline \multirow{4}{*}{$\begin{array}{l}\text { Household } \\
\text { size }\end{array}$} & \multirow{4}{*}{3} & $\mathrm{~F}$ & 19.32 & 16.07 & 9.32 & 19.04 & 0.24 \\
\hline & & df & 2.00 & 2.00 & 2.00 & 2.00 & 2.00 \\
\hline & & SS (between) & 1.29 & 0.27 & 0.62 & 1.27 & 0.01 \\
\hline & & Significance & a & $a$ & a & $a$ & a \\
\hline \multirow{4}{*}{$\begin{array}{l}\text { Household } \\
\text { income }\end{array}$} & \multirow{4}{*}{5} & $\mathrm{~F}$ & 38.56 & 4.54 & 27.17 & 0.12 & 24.4 \\
\hline & & $d f$ & 4.00 & 4.00 & 4.00 & 4.00 & 4.00 \\
\hline & & SS (between) & 5.14 & 0.36 & 2.17 & 0.01 & 2.6 \\
\hline & & Significance & a & a & a & $b$ & a \\
\hline \multirow{4}{*}{$\begin{array}{l}\text { Number of } \\
\text { employed } \\
\text { persons }\end{array}$} & \multirow{4}{*}{3} & $\mathrm{~F}$ & 29.30 & 5.40 & 2.03 & 3.46 & 2.24 \\
\hline & & $d f$ & 2.00 & 2.00 & 2.00 & 2.00 & 2.00 \\
\hline & & SS (between) & 1.95 & 0.24 & 0.14 & 0.15 & 0.10 \\
\hline & & Significance & a & $b$ & a & $b$ & a \\
\hline
\end{tabular}

Table 6. ANOVA results by trip mode of travel

\begin{tabular}{|c|c|c|c|c|c|}
\hline \multirow[b]{2}{*}{ Variable } & \multirow[b]{2}{*}{ Category } & \multirow[b]{2}{*}{ Statistics } & \multicolumn{3}{|c|}{ Trip by transport } \\
\hline & & & Private car & Minibus/tricycle & Walking \\
\hline \multirow{4}{*}{ Household size } & \multirow{4}{*}{3} & $\mathrm{~F}$ & 5.34 & 8.28 & 0.36 \\
\hline & & $d f$ & 2.00 & 2.00 & 2.00 \\
\hline & & SS (between) & 0.02 & 0.04 & 0.73 \\
\hline & & Significance & a & a & a \\
\hline \multirow{4}{*}{ Household income } & \multirow{4}{*}{5} & $F$ & 16.57 & 17.29 & 3.23 \\
\hline & & df & 4.00 & 4.00 & 4.00 \\
\hline & & SS (between) & 2.21 & 2.31 & 0.43 \\
\hline & & Significance & a & a & $b$ \\
\hline
\end{tabular}




\begin{tabular}{|c|c|c|c|c|c|}
\hline \multirow{3}{*}{ Car Ownership } & \multirow{4}{*}{3} & $\mathrm{~F}$ & 13.66 & 6.00 & 6.36 \\
\hline & & $d f$ & 2.00 & 2.00 & 2.00 \\
\hline & & SS (between) & 0.61 & 0.00 & 0.28 \\
\hline & & Significance & a & a & a \\
\hline
\end{tabular}

$a=$ significant at $95 \%$ or beyond; $b=$ not significant at $95 \%$ of beyond, SS = sum of squares, $F=F$ Score, df $=$ degree of freedom. Table 7: Cross Classification Trip Rates of Household Income versus Household Size

\begin{tabular}{|c|c|c|c|c|}
\hline \multirow[b]{2}{*}{ Area } & \multirow{2}{*}{ Household Income ( } & \multicolumn{3}{|c|}{ Household Size } \\
\hline & & $1-5$ & $6-10$ & $>10$ \\
\hline \multirow{5}{*}{ Urban Residential area } & $<18,000$ & 0.41 & - & - \\
\hline & $18,000-25,000$ & 0.81 & 1.69 & - \\
\hline & $25,001-32,000$ & 0.96 & 1.78 & 0.89 \\
\hline & $32,001-40,000$ & 1.01 & 2.01 & 1.07 \\
\hline & $>40,000$ & 1.57 & 2.36 & 1.15 \\
\hline
\end{tabular}

Table 8: Cross classification rates of car ownership versus household size.

\begin{tabular}{lllll}
\hline \multirow{2}{*}{ Area } & \multirow{2}{*}{ Car Ownership } & \multicolumn{3}{c}{ Household Size } \\
\cline { 3 - 5 } Urban Residential area & 0 & 0.70 & $6-10$ & $>10$ \\
& $1-2$ & 0.97 & 1.04 & 0.76 \\
& $>2$ & 0.99 & 1.14 & 0.88 \\
\hline
\end{tabular}

Table 9: Cross Classification Rates of Household Income versus Car Ownership.

\begin{tabular}{lllll}
\hline \multirow{2}{*}{ Area } & \multirow{2}{*}{ Household Income (A) } & \multicolumn{3}{c}{ Car Ownership } \\
\cline { 3 - 5 } & & 0 & $1-2$ & $>2$ \\
\hline \multirow{3}{*}{ Urban Residential area } & 18,0000 & 0.37 & - & - \\
& $25,001-32,000$ & 0.41 & 0.77 & - \\
& $32,001-40,000$ & 0.63 & 0.89 & 1.45 \\
& $>40,000$ & 0.66 & 1.18 & 1.72 \\
\hline
\end{tabular}

\section{CONCLUSION}

From the results of the study, it can be seen that work trips produced the highest total trip rate, followed by religious trips in land use of the study area. Similarly, private car trips contributed the highest total trip rate which could be attributed to the ineffective public/mass transportation system in the study area. The increase in car usage could be one of the primary cause of congestion along Oron road during peak periods. Household size appeared the most significant socio-economic variable that influence trip making in residential land uses in Uyo. Cross Classification rates of household income versus household size was found to have the highest trip rate in the cell and the lowest trip rate found in household income versus car ownership. This implies that households' income and household size are the basic socio-economic variables that influence trip making in residential land use in Uyo. Hence, the variables should be considered when building a functional cross-classification model.

\section{REFERENCES}

[1] Khisty, J. C. and Lall B. K. Transportation Engineering, Prentice Hall, New Dehi, 2008.

[2] Etu, J.E. Oyedepo, O. J. "Forecasting Trip Generation for High Density Residential Zones of Akure, Nigeria: Comparability of Artificial Neural Network and Regression Models" Journal of Civil Engineering, Science and Technology Vol. 9, Issue 2, 2018. pp. $76-86$.

[3] Bowman, J. K. and Ben-Akiva, M. E. "Activitybased Disadvantage Travel Demand. Model system with activity schedules", Transportation Research Part A: Policy and Practice, vol. 3, number 5, 2001, pp. 1 - 28.

[4] Kassoff, $\mathrm{H}$ and Deutschman H., "Trip Generation: A Critical Appraisal", Transportation Research Board, vol. 9, number 7, 1909, pp 15 - 30.

[5] Fadairo, G. "Traffic Congestion in Akure, Ondo State, Nigeria: Using Federal University of Technology, Akure Road as a Case Study". International Journal of Arts and Commerce, vol. 2, number 5, 2013, pp. $67-76$. 
[6] Ekong, D. "Trip Generation Models for a Developing City in Nigeria". International Journal of Social Science, vol. 4, number 1, 2005, pp 10 - 19.

[7] Al-Masaeid. H. R. and Fayyad, S. S "Estimation of Trip Generation Rates for Residential Areas in Jordan, Jordan", Journal of Civil Engineering, vol. 12 , number 1,2018 , pp. $162-172$

[8] Wilfred, G. Bwire, H. Maltsson, L. and Jonsson, D. "Effect of land use on trip generation in Urban areas: Comparison between estimated trip generation rates and planning practices". Paper presented at the $34^{\text {th }}$ Annual Southern African Transport Conference, Dares Salaam, Tanzania, July 9 -12, 2015, pp. $776-787$.

[9] Miller, J., Hoel, L., Goswann, A, Ulmer, J. "Borrowing Residential Trip Generation Rates", Journal of Transportation Engineer. Washington. D.C. vol. 132, number 2, 2006, pp. 105111.

[10] Oyedepo O. J. and Makinde. O., "Regression Model of Household Trip Generation of AdoEkiti Township in Nigeria". Journal of Science Resources, vol. 28, number 1, 2009, 32 - 140.
[11] Justin, S. C., Dongjae, J., Jaekyung, K., and Taeseok, K. "Comparative Analysis of Trip Generation Models: Results Using Home-base Work Trips in the Seoul Metropolitan Area", International Journal of Transportation Research, vol. 6, number 2, 2014, pp.78- 88.

[12] Takyi I.K. "Trip Generation Analysis in a Developing Country Context". Transportation Research Record 1285. TRANSLAB, University of Pennsylvania, 3400 Walnut Street, Philadelphia, Pa. 19104-6208. vol. 1, number 2, 1983, pp. $9-21$.

[13] Essien, E. and Cyrus, S. "Detection of Urban Development in Uyo (Nigeria) Using Remote Sensing". Land, 8, 102; 2019, pp.1-13. doi:10.3390/land8060102

[14] AKGSonline. Population of Akwa Ibom State. Available online: https://www.aksgonline.com/about_people_p opulation.html (accessed on 5 May 2019).

[15] Kadiyali, L. R. Traffic Engineering and Transport Planning, $7^{\text {th }}$ ed, Khama Publishers, New Delhi, 2012. 